\title{
MIF and CXCL12 in cardiovascular diseases: functional differences and similarities
}

\author{
Emiel P. C. van der Vorst ${ }^{1 *}$, Yvonne Döring ${ }^{1 *}$ and Christian Weber ${ }^{1,2,3 *}$ \\ ${ }^{1}$ Institute for Cardiovascular Prevention, Ludwig-Maximilians-University Munich, Munich, Germany, ${ }^{2}$ German Centre for \\ Cardiovascular Research (DZHK), Partner Site Munich Heart Alliance, Munich, Germany, ${ }^{3}$ Cardiovascular Research Institute \\ Maastricht (CARIM), Maastricht University, Maastricht, Netherlands
}

\section{OPEN ACCESS}

Edited by:

Marcus Thelen,

Institute for Research in Biomedicine,

Switzerland

Reviewed by:

Mariagrazia Uguccioni,

Institute for Research in Biomedicine,

Switzerland

Thierry Calandra,

Centre hospitalier universitaire

vaudois, Switzerland

*Correspondence:

Emiel P. C. van der Vorst,

Yvonne Döring, and Christian Weber,

Institute for Cardiovascular

Prevention, Ludwig-Maximilians-

University Munich, Pettenkoferstr. 9,

Munich 80336, Germany

emiel.van_der_vorst@med.

uni-muenchen.de;

yvonne.doering@med.unimuenchen.de;

christian.weber@med.unimuenchen.de

Specialty section:

This article was submitted to Chemoattractants, a section of the journal Frontiers in Immunology

Received: 24 April 2015

Accepted: 07 July 2015

Published: 21 July 2015

Citation:

van der Vorst EPC, Döring $Y$ and Weber C (2015) MIF and CXCL12 in cardiovascular diseases: functional

differences and similarities.

Front. Immunol. 6:373.

doi: 10.3389/fimmu.2015.00373
Coronary artery disease (CAD) as part of the cardiovascular diseases is a pathology caused by atherosclerosis, a chronic inflammatory disease of the vessel wall characterized by a massive invasion of lipids and inflammatory cells into the inner vessel layer (intima) leading to the formation of atherosclerotic lesions; their constant growth may cause complications such as flow-limiting stenosis and plaque rupture, the latter triggering vessel occlusion through thrombus formation. Pathophysiology of CAD is complex and over the last years many players have entered the picture. One of the latter being chemokines (small 8-12 kDa cytokines) and their receptors, known to orchestrate cell chemotaxis and arrest. Here, we will focus on the chemokine CXCL12, also known as stromal cell-derived factor 1 (SDF-1) and the chemokine-like function chemokine, macrophage migration-inhibitory factor (MIF). Both are ubiquitously expressed and highly conserved proteins and play an important role in cell homeostasis, recruitment, and arrest through binding to their corresponding chemokine receptors CXCR4 (CXCL12 and MIF), ACKR3 (CXCL12), and CXCR2 (MIF). In addition, MIF also binds to the receptor CD44 and the co-receptor CD74. CXCL12 has mostly been studied for its crucial role in the homing of (hematopoietic) progenitor cells in the bone marrow and their mobilization into the periphery. In contrast to CXCL12, MIF is secreted in response to diverse inflammatory stimuli, and has been associated with a clear pro-inflammatory and pro-atherogenic role in multiple studies of patients and animal models. Ongoing research on CXCL12 points at a protective function of this chemokine in atherosclerotic lesion development. This review will focus on the role of CXCL12 and MIF and their differences and similarities in CAD of high risk patients.

Keywords: cardiovascular disease, atherosclerosis, chemokines, macrophage migration-inhibitory factor, CXCL12

\section{Introduction}

Worldwide, cardiovascular disease (CVD) is the leading cause of death, accounting for more than 15 million deaths annually $(1,2)$. CVD is a collection of various diseases, but the most common and most severe are coronary artery disease $(\mathrm{CAD})$ and cerebrovascular disease. In a high percentage of patients, these diseases eventually result in a myocardial infarction (MI) or stroke, respectively. CVD has not only a major impact on personal health, but also the economic burden is quite high. Besides the high mortality rates, patients who do survive are often hospitalized or should receive 
lifelong treatment, leading to high healthcare costs. In the United States alone, these costs are even more than $\$ 312$ billion per year, indicating the magnitude of economic burden caused by CVD (3). Finally, the social burden on the direct environment of CVD patients should not be underestimated.

In recent years, or even decades a lot of research has been performed to better understand the exact pathology behind CVDs. Currently, atherosclerosis, a chronic inflammatory disease mainly affecting medium and large-sized arteries, has been identified as the main underlying cause of CVD (4). Upon activation of the vascular endothelial layer, lipids, immune cells, and cell debris start to accumulate in the vessel wall, forming initial lesions. These lesions will over time progress and grow in size, thereby partially or even fully occluding the artery. More often, however, the full occlusion of the vessel is caused by a rupture of the atherosclerotic lesion resulting in thrombus formation (4). Excessive growth or rupture of the lesion both result in ischemic areas in downstream tissues. Most commonly this occurs in arteries from the heart or the brain, leading to MI or stroke, respectively. To date, there is still no absolute suitable therapy available to cure or reverse atherosclerosis. Better understanding of this pathology will increase the ability to prevent it, and create opportunities to develop therapeutic strategies to cure it, or at least slow down the disease progression.

This review will give a short overview of the current knowledge about atherosclerosis, mainly focusing on the inflammatory aspects and the role of chemokines. Subsequently, the role of two important inflammatory mediators that recently have been connected with CVD and atherosclerosis will be discussed and put into clinical perspective, namely the chemokines CXCL12 and macrophage migration-inhibitory factor (MIF, Table 1 and Figure 1).

\section{Atherosclerosis}

\section{Risk Factors}

Already a multitude of risk factors have been described for CVDs, mainly derived from epidemiological studies. Main risk factors include psychosocial factors, hypertension, changes in lowdensity lipoproteins (LDL) and high-density lipoproteins (HDL) cholesterol levels, physical inactivity, smoking, obesity, lack of fruits and vegetables consumption, and alcohol and diabetes mellitus (20-22). All these risk factors vary greatly in prevalence and potency to influence CVD and are often combined in patients with severe atherosclerosis, supporting the concept that atherosclerosis is a multifactorial, complex disease (22). A worldwide case-control study showed that these nine factors combined account for more than $90 \%$ of the cardiovascular risk (21), where smoking and abnormal lipids already account for two-thirds of the risk. Additionally, many patients, especially high risk patients, have genetic predispositions for atherosclerosis (23). Some of these risk factors should be relatively easy to prevent with life-style adjustments. However, due to the multifactorial characteristics of the disease, identification of the precise mechanisms of action, whereby these risk factors influence atherosclerosis, is a key and crucial step in the road toward therapeutic strategies. This way for example statins, lipid modulating drugs, have been developed that lower LDL cholesterol levels and thereby inhibit the progression of atherosclerosis. Recently, Nahrendorf and Swirski very nicely reviewed the possible influence of various risk factors on the crosstalk between hematopoiesis, immune cells, and the cardiovascular system (22).

\section{Atherosclerosis Initiation}

Formation of atherosclerotic lesions occurs predominantly at predisposed sites, i.e., sites of disturbed laminar flow, like bifurcations and curvatures (24), thereby disturbing the normal, quiescent state of the endothelium. The resulting increased permeability of the endothelial layer leads to the accumulation of lipids, more specifically LDL, in the subendothelial layer of the arterial wall (25). LDL is very susceptible to oxidation, mainly caused by myeloperoxidase, lipoxygenenases or by reactive oxygen species such as $\mathrm{HOCl}$, resulting in oxidized-LDL particles (oxLDL) (26). The modification of LDL can activate the endothelial cells (ECs) and tissue-resident macrophages (27). Subendothelial/ extravasated LDL will be oxidized and taken up by resident macrophages via scavenger receptors (SRs), mainly SR-A, SR-B1, and cluster of differentiation (CD) $36(28,29)$. Intracellularly, oxLDL will be hydrolyzed into free cholesterol and fatty acids in late endosomes (30). Free cholesterol is subsequently transported to the endoplasmic reticulum where it undergoes re-esterification to cholesteryl esters by the acyl-CoA:cholesterol ester transferase (ACAT) enzyme (31). This accumulation of cholesteryl esters will transform the macrophages into foam cells, a characteristic hallmark of early atherosclerosis. Not only the uptake and storage of cholesterol are disturbed, but also the excretion mechanisms are disturbed. ATP binding cassette transporters A1 and G1 (ABCA1 and $A B C G 1)$ are the major contributors to this cholesterol efflux through reverse cholesterol transport $(\mathrm{RCT})(32,33)$. Cholesterol will efflux toward HDL, making HDL beneficial for atherosclerosis development (32). Normally, this efflux mechanism is upregulated upon lipid loading, however, during hypercholesterolemia this route is compromised via TLR4-induced downregulation of the cholesterol transporters, further favoring the conversion of macrophages to foam cells (34).

This macrophage activation, due to the lipid loading, together with the activation of ECs will lead to more vascular inflammation, by the secretion of various cytokines, chemokines, and adhesion molecules (35). The inflammation will result in the attraction of mainly monocytes but also other immune cells, like T- and B-lymphocytes and neutrophils to the site of injury and lesion formation (26). In humans, two main subsets of circulating monocytes have been described based on their expression of CD14 and CD16 (36). Over 90\% of the circulating monocytes are $\mathrm{CD} 14^{\mathrm{high}} / \mathrm{CD} 16^{-}$and are called the classical monocytes (37). The other population, the non-classical monocytes are CD14 ${ }^{\text {low }} /$ CD16 ${ }^{\text {high }}$ (36). These distinct subsets also show differential expression of chemokine receptors (38). The classical monocytes express, for example, high levels of CCR2, a receptor for CCL2 (39). $\mathrm{CX}_{3} \mathrm{CR} 1$ is expressed on both subtypes, but the expression on non-classical monocytes is twofold higher compared to that on the classical monocytes $(40,41)$. In mice, also two main subtypes of circulating monocytes can be identified, discriminated mainly by the expression of Ly6C, i.e., the Ly6 $\mathrm{C}^{\text {high }}$ (classical) and 
TABLE 1 | Overview of human studies on CXCL12 and MIF in CVD.

\begin{tabular}{|c|c|c|}
\hline Study design & Outcome & Reference \\
\hline \multicolumn{3}{|l|}{ CXCL12 } \\
\hline Genome-wide association studies in over 100,000 patients & $\begin{array}{l}\text { CXCL12 locus on chromosome } 10 q 11 \text { is clearly associated with CAD, indicating that } \\
\text { CXCL12 may be involved in CVD development }\end{array}$ & (5) \\
\hline $\begin{array}{l}\text { Western blot analysis and immunohistochemical analysis of } \\
\text { human plaques }\end{array}$ & $\begin{array}{l}\text { Atherosclerotic lesions express high levels of CXCL12, in contrast to vascular cells of } \\
\text { healthy vessels, associating CXCL12 with CVD }\end{array}$ & (6) \\
\hline Cohort study of 904 patients with CAD & $\begin{array}{l}\text { Platelet CXCL12 expression is increased in angina patients, though clinical significance } \\
\text { remains to be elucidated }\end{array}$ & (7) \\
\hline $\begin{array}{l}\text { Cohort study of } 215 \text { patients with symptomatic CAD } \\
\text { undergoing percutaneous coronary intervention }\end{array}$ & $\begin{array}{l}\text { CXCR4 and ACKR3 are more highly expressed on platelets from CAD patients, } \\
\text { associating receptors of CXCL12 to CVD }\end{array}$ & (8) \\
\hline Plasma CXCL12 evaluation of 60 CAD patients & $\begin{array}{l}\text { Plasma CXCL12 levels and surface expression of CXCR4 in peripheral blood mononuclear } \\
\text { cells are decreased in angina patients, indicating that CXCL12 could be beneficial for CVD }\end{array}$ & (9) \\
\hline Cohort study of 785 patients undergoing angiography & Plasma CXCL12 levels are superior to traditional risk factors in predicting CAD outcomes & $(10)$ \\
\hline Evaluation of 1,000 patients hospitalized due to chest pain & $\begin{array}{l}\text { Platelet-derived CXCL12 expression occurs fast after injury in CAD patients, as early as } \\
30 \text { min, indicating that CXCL12 might be very useful as biomarker }\end{array}$ & $(11)$ \\
\hline \multicolumn{3}{|l|}{ MIF } \\
\hline $\begin{array}{l}\text { Single nucleotide polymorphism (SNP) evaluation of } 459 \mathrm{Ml} \\
\text { patients and healthy controls }\end{array}$ & MIF single nucleotide polymorphism (rs755622) is associated with MI risk & $(12)$ \\
\hline $\begin{array}{l}\text { MIF analysis in healthy and diseased internal mammary } \\
\text { arteries }\end{array}$ & $\begin{array}{l}\text { MIF is abundantly expressed in human atherosclerotic lesions, throughout lesion } \\
\text { development, associating MIF with CVD }\end{array}$ & $(13)$ \\
\hline $\begin{array}{l}\text { Immunohistochemical analysis of human atherosclerotic } \\
\text { plaques }\end{array}$ & $\begin{array}{l}\text { MIF is associated with fibrous cap weakening, by inducing protease expression and } \\
\text { activity, associating MIF with plaque instability }\end{array}$ & $(14)$ \\
\hline $\begin{array}{l}\text { Evaluation of } 286 \text { patients with symptomatic CAD } \\
\text { undergoing percutaneous coronary intervention }\end{array}$ & $\begin{array}{l}\text { Plasma MIF levels are increased in CVD patients, associated with inflammatory marker } \\
\text { expression }\end{array}$ & $(15)$ \\
\hline Prospective study of 617 patients with CAD & $\begin{array}{l}\text { High plasma MIF levels are an independent risk factor for future coronary events in CVD } \\
\text { patients with impaired glucose tolerance or type } 2 \text { diabetes mellitus, associating MIF with } \\
\text { CVD development }\end{array}$ & $(16)$ \\
\hline $\begin{array}{l}\text { Plasma MIF and Grem } 1 \text { evaluation in } 286 \text { patients with } \\
\text { CVD }\end{array}$ & $\begin{array}{l}\text { High plasma Grem1/MIF ratio is associated with CVD and the grade of plaque stability, } \\
\text { indicating MIF as a possible novel risk marker in CVD patients }\end{array}$ & $(17)$ \\
\hline $\begin{array}{l}\text { Evaluation of MIF levels in patients with chronic stable } \\
\text { angina }\end{array}$ & $\begin{array}{l}\text { MI patients have higher plasma MIF levels which are predictive of final infarct size and } \\
\text { remodeling, suggesting a role for MIF as biomarker }\end{array}$ & $(18)$ \\
\hline $\begin{array}{l}\text { Prospective case-control study nested in the EPIC-Norfolk } \\
\text { cohort in people without prior history of MI or stroke }\end{array}$ & $\begin{array}{l}\text { Association of MIF with MI risk or death due to CVD is not very strong in humans without } \\
\text { prior history of CVD, indicating that more research is necessary before choosing MIF as } \\
\text { therapeutic target }\end{array}$ & $(19)$ \\
\hline
\end{tabular}

Ly6C low (non-classical) monocytes (42). Similar to the human subpopulations mouse classical monocytes express high levels of CCR2, while non-classical monocytes express CX $_{3}$ CR1 (43). Hypercholesterolemia, a common characteristic of atherosclerosis increases Ly6 $\mathrm{C}^{\text {high }}$ monocyte levels $(44,45)$. Additionally, Ly6C ${ }^{\text {high }}$ classical monocytes form the main subtype that will migrate to the site of injury (46).

The mechanism of monocyte recruitment and adhesion consists of complex interactions between various adhesion molecules and chemokines. The exact role of various chemokines in atherosclerosis will be discussed later. In short, the monocyte adhesion cascade consists of several steps. The first step in this cascade is the capture and rolling phase, where various chemokines and selectins on the luminal side of the activated endothelium play a crucial role $(35,47)$. The second step is the firm adhesion of these monocytes to the endothelium. In this phase, vascular cell adhesion molecule 1 (VCAM1) and intercellular adhesion molecule 1 (ICAM1) present on the endothelium are essential, since they attach firmly to the integrins very late antigen 4 (VLA4) and lymphocyte function-associated antigen 1 (LFA1), respectively, present on the monocytes (47). VCAM1, ICAM1, and E-selectin form clusters to initiate cytoskeletal reorganization, necessary for subsequent transmigration (48). These clusters, also called docking structures, have been shown to be located on upright endothelial membrane processes and are organizes as the so-called transmigratory cups by tetraspanins (49). Monocyte transmigration across the endothelial layer is mainly directed by various chemokines and their receptors (50). Next to these chemokines, also the endothelial junction molecules, platelet endothelial cell adhesion molecule 1 (PECAM1), VE-Cadherin, and junctional adhesion molecules (JAMs) play a crucial role as regulators of EC permeability and leukocyte transmigration (51). Monocytes have two ways to transmigrate, a paracellular route and a transcellular route. The paracellular route leads monocytes through the endothelial junctions, whereas the transcellular route uses fusing vesicles in the endothelium cell cytoplasm for transmigration (52). Once inside the vessel wall, monocytes can differentiate into macrophages, driven by macrophage colony-stimulating factor (M-CSF) (53). Macrophages are a heterogeneous cell population, consisting of two main groups, the classically activated, inflammatory M1 macrophages and the alternatively activated, inflammation resolving M2 macrophages (54). Various cytokines play a role in this polarization of macrophages, such as IL-10 and interferon- $\gamma$ (55). Both types of macrophages are present in atherosclerotic lesions, where the balance between them is of great importance for either plaque development or resolving inflammation (56). These attracted leukocytes will again be exposed to the oxidized-lipid-rich environment of the developing lesion, forming foam cells. Thereby a vicious circle of 


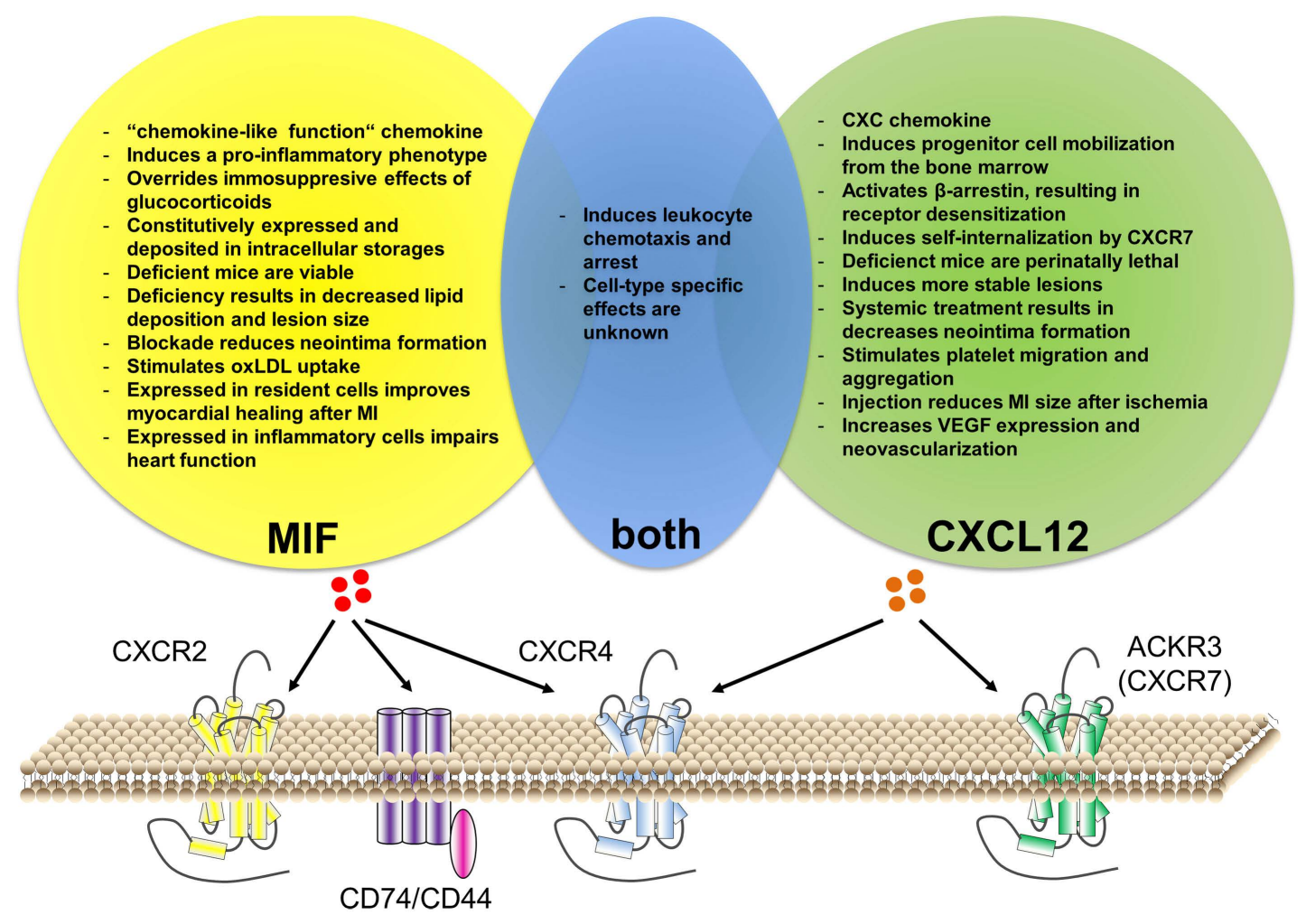

FIGURE 1 | Similarities and differences of CXCL12 versus MIF function in cardiovascular disease. Both CXCL12 and MIF can bind to CXCR4. Additionally, CXCL12 can bind to ACKR3 (CXCR7), while MIF binds to CXCR2 and CD74/CD44. Although MIF interaction with ACKR3 has been described for platelets, it is still unclear whether this is via direct binding or via receptor heterodimerization. Both chemokines have an important role in leukocyte recruitment, although cell-type-specific effects remain unknown. Besides this, CXCL12 and MIF have individual functions associated with cardiovascular disease. leukocyte attraction and lipid accumulation is formed, stimulating atherosclerosis development.

\section{Plaque Progression}

When lesional macrophages take up so many lipids and debris, many will eventually go into apoptosis. In early plaque development apoptosis is not considered detrimental, since neighboring macrophages will take up and eliminate the apoptotic debris, a process called efferocytosis (56). However, when plaque development progresses, the excessive uptake of lipids and debris continues and eventually leads to cellular stress and impaired efferocytosis (57). This will result in the accumulation of apoptotic debris and apoptotic macrophages will go into secondary necrosis, leading to the formation of the necrotic core which is characteristic of more advanced lesions $(56,58)$. The necrotic core will significantly contribute to the lesional inflammation, and thus progression, and also contains pro-thrombotic factors that will lead to a thrombus when it comes into contact with platelets (59). To prevent this from happening, a fibrous cap is formed between the necrotic core and the lumen, by deposition of mainly collagen and elastin by intimal smooth muscle cells (SMCs) (60). Various cytokines and growth factors, produced by leukocytes, are important for the migration of intimal SMCs to the intima and for the extracellular matrix production (60). Plaques with a big fibrous cap are considered to be more stable atherosclerotic lesions, i.e., less prone to rupture. However, macrophages can also produce matrix metalloproteinases (MMPs), which are capable of degrading extracellular matrix proteins (59). Fibrous cap degradation and thus thinning makes the lesion more vulnerable and can eventually lead to a plaque rupture, releasing pro-thrombotic material into the bloodstream resulting in thrombus formation and obstruction of blood flow. This can cause ischemia to distal regions and result in a MI or stroke (58).

\section{Chemokines in Atherosclerosis}

Chemokines are the largest family of cytokines, consisting of small molecules $(8-12 \mathrm{kDa})$ that exert chemotactic effects on cells (61). This large family is divided into four subclasses, being $\mathrm{C}$, $\mathrm{CC}, \mathrm{CXC}$, and $\mathrm{CX}_{3} \mathrm{C}$. This classification is based on the position of the $\mathrm{N}$-terminal cysteine residues (62). In addition to these four canonical chemokine classes, a fifth subclass consisting of molecules that share functional similarities with chemokines has emerged, referred to as "chemokine-like function" (CLF) chemokines (63). These non-canonical chemokines do exert some CLFs, but do not contain the specific N-terminal cysteine residue characteristic of canonical chemokines (63). Chemokines can bind to chemokine receptors, which are classified according to the chemokine they bind. Most chemokine receptors will activate $G$ proteins and intracellular signaling upon binding and are therefore part of the $\mathrm{G}$ protein-coupled receptor family. However, 
several receptors, the so-called atypical chemokine receptors, are $\mathrm{G}$ protein signaling independent and rather play a role in the scavenging of chemokines (64). Chemokines and chemokine receptors are expressed on various cell types, like ECs, SMCs, and leukocytes. Originally, chemokines were discovered for their capacity of directing leukocytes toward sites of inflammation (65). Thereby, chemokines also play a crucial role in atherosclerosis.

Chemokines already play a role in a very early stage of atherosclerosis development. Recently, it was shown that lysophosphatidic acid, a component of LDL mediates the release of CXCL1 from ECs (66). Studies in atherosclerotic prone $\mathrm{ApoE}^{-/-}$mice fed a cholesterol-rich diet show that CXCL1 is not only important for the mobilization of the classical, or inflammatory, monocytes to the site of inflammation, but also important for neutrophil recruitment via the receptor CXCR2 (66-68).

The involvement of various chemokines and their receptors in monocyte recruitment has already been well described (69). However, during the recent decade these described involvements have been revised and are still being greatly debated. Using a highly sophisticated technique of transferring atherosclerotic aortic arches from $\mathrm{ApoE}^{-/-}$mice into specific chemokine receptor knockout mice, it was shown that inflammatory monocytes require CCR2, CCR5, and $\mathrm{CX}_{3} \mathrm{CR} 1$ to migrate into the atherosclerotic lesion, while the patrolling monocytes used CCR5 for recruitment (70). However, this view again changed recently using adoptive transfer experiments with pharmacological inhibition of the specific chemokine receptors. Here it was shown that the inflammatory Ly6 $\mathrm{C}^{\text {high }}$ monocytes use CCR1 and CCR5 for recruitment, rather than the previously shown CCR2 and $\mathrm{CX}_{3} \mathrm{CR} 1$ (68). CCR2-deficient mice on an atherosclerosis-prone background did, however, result in a significantly reduced lesion size in mice. Based on the adoptive transfer study and the fact that CCR2-deficient mice show reduced circulating monocyte counts, it can be suggested that the beneficial effect on atherosclerosis is due to its effects on monocyte release from the bone marrow, rather than directs effects on monocyte recruitment $(71,72)$. Also for $\mathrm{CX}_{3} \mathrm{CR} 1$-deficient mice, it was observed that these animals have reduced atherosclerosis development, implicating $\mathrm{CX}_{3} \mathrm{CR} 1$ in atherogenesis (73). However, instead of effects on monocyte recruitment, $\mathrm{CX}_{3} \mathrm{CR} 1$ seemed to play an important role in cell survival. Thus, deficiency of this chemokine resulted in increased apoptosis of plaque macrophages, thereby reducing lesion development (73). CCR1 and CCR5, which do seem to be involved in leukocyte recruitment, both have several specific ligands, but also share ligands like CCL3 and CCL5. However, looking at the exact effects of both receptors on atherogenesis, there are distinct differences. CCR5 deficiency results in a clear reduction of diet-induced atherosclerosis in mice, while CCR1 deficiency increased lesion development $(74,75)$.

In the later stages of atherosclerotic lesion development, chemokines also still play an important role. The best-studied chemokine receptor in this stage, especially with respect to plaque regression, is CCR7. It has been shown in various studies that CCR7 is necessary for the egress of macrophages during lesion regression (76-78). However, CCR7 in T cells seems to play a proatherogenic role. CCR7-deficient T cells show an impaired entry and exit capacity from atherosclerotic lesions (79). Combined,
CCR7 is thus involved in macrophage egress from lesions and $\mathrm{T}$ cell migration. In these later stages of lesion development also CXCL10 is crucially involved, especially in plaque stability. Inhibition of CXCL10 resulted in relatively more SMCs and a more stable plaque phenotype (80).

These results clearly show that the chemokine system plays an important role in all stages of atherosclerotic lesion development, but underlines that these interactions are very complex and elaborate. Additional research is still needed to even further elucidate the role of this system in atherosclerosis and CVD in general. Besides the already described chemokines involved in atherosclerosis, in the recent years, more and more research has been focusing on two yet undiscussed chemokines, being CXCL12 and MIF. The remainder of this review will specifically focus on the role of these two chemokines in atherosclerosis and CVD.

\section{CXCL12}

\section{Ligand/Receptor Characteristics}

CXCL12, also known as stromal cell-derived factor 1 (SDF-1), is one of the 17 members of the CXC chemokine family (5). Structurally, this group of chemokines can be further subdivided into two groups, depending on the presence of a specific amino acid motif [glutamic acid-leucine-arginine (ELR)] before the first cysteine group (81). Interestingly, this subdivision showed also to be a functional separation since ELR-positive chemokines attract neutrophils, while ELR-negative chemokines, such as CXCL12, attract T lymphocytes and natural killer cells $(82,83)$. CXCL12 consists on its turn again of six isoforms, derived from alternative splicing (84). The classical isoforms are CXCL12- $\alpha$ and CXCL12- $\beta$, which are expressed throughout the body and so far functionally indistinguishable (84). Other isoforms are called CXCL12- $\gamma,-\delta,-\varepsilon$, and $-\varphi$, which show a more restricted expression pattern and are until now much less studied. All isoforms share the same $\mathrm{N}$-terminal sequence, but differ in the C-terminal region (84).

The most important receptor for CXCL12 is CXCR4, which is also expressed on a wide variety of cells $(85,86)$. CXCR4 is a $\mathrm{G}$ protein-coupled receptor and binding of CXCL12 will induce intracellular signaling via a classical heterotrimeric $G$ protein (86). Receptor activation has been shown to trigger MAPK and PI3K signaling, but also calcium mobilization (87). Additionally, activation of CXCR 4 results in $\beta$-arrestin recruitment, resulting in the endocytosis of CXCR4 and thus receptor desensitization (88).

More recently, a second receptor for CXCL12 was identified, being ACKR3 (CXCR7) which is highly expressed on monocytes and mature B cells (89). This receptor has even a 10-fold higher affinity for CXCL12 than CXCR4. Binding of CXCL12 to the receptor does, however, not result in the classical leukocyte chemotaxis response or coupling with $\mathrm{G}$ proteins to induce intracellular signaling. ACKR3 is implicated in cell growth and survival (90). However, the main function of ACKR3 seems to be as a decoy receptor, since receptor stimulation by CXCL12 enhances internalization of ACKR3 and thereby delivery of its ligands to the lysosomes for degradation $(91,92)$. This way, ACKR3 activation would reduce CXCL12/CXCR4 signaling. However, since CXCL12 scavenging also prevents the downregulation of CXCR4, 
ACKR3 could also well be beneficially influencing CXCR4mediated effects (93). However, ACKR3 stimulation has also been shown to result in downregulation of CXCR4 (94). On the other hand, CXCR4 seems also to be influencing ACKR3, since the widely used antagonist for CXCR4 AMD3100 has recently been shown to have agonistic effects on ACKR3 (95). ACKR3 can have intracellular signaling effects on MAPK, but these are purely $\beta$-arrestin mediated (96). Altogether, these results clearly show that there is a complex interaction between CXCL12/CXCR4 and ACKR3.

\section{CXCL12 and Stem-/Progenitor-Cell Mobilization}

The importance of CXCL12 in general has been clearly shown in mice that have a total CXCL12 deficiency. These animals die already perinatally due to major defects in hematopoiesis, vasculo-, cardio-, and neurogenesis (97). These embryonic defects are indicative for the important role of the CXCL12/CXCR4 axis in progenitor cell migration, but also for survival and chemotaxis of murine embryonic stem cells during embryogenesis (98). The role of CXCL12/CXCR4 in this mobilization from the bone marrow has already been well studied, not only for hematopoietic stem cells, but also for EC and SMC progenitor cells (99). In physiological conditions, hematopoietic stem cells are retained in the bone marrow by high expression of CXCL12 by stromal cells (97). In the clinic, modulation of the CXCL12/CXCR4 axis by granulocyte colony-stimulating factor (G-CSF) is already used to mobilize stem cells from the bone marrow to the circulation. G-CSF has various ways of modulating this axis, reviewed in (97). Additionally, the role of CXCL12/CXCR4 is confirmed by using the CXCR4 antagonist AMD3100, which results in decreased bone marrow CXCL12 levels, thereby favoring mobilization of stem cells (100).

\section{CXCL12 in Atherosclerosis}

Mobilization of hematopoietic stem cells, but also progenitor cells like endothelial progenitor cells (EPCs) and smooth muscle progenitor cells (SPCs), has also been implicated in various pathologies like atherosclerosis $(101,102)$. A recent study showed that injections of CXCL12 in mice developing atherosclerosis resulted in more stable lesions, characterized by more SMCs and a thicker fibrous cap (103). These plaque-stabilizing effects were mediated by an increased recruitment of SPCs to these lesions. Supporting this finding, direct injection of SPCs in mice reduces atherosclerotic lesion development and improves the stability (104). Besides SPCs, also EPCs were shown to be involved in atherogenesis, since infusion of EPCs, or AMD3100 treatment triggering EPC mobilization resulted in a beneficial effect on lesion regression (105). Together, these studies show atheroprotective effects of the CXCL12/CXCR4 axis, mediated by progenitor mobilization.

Besides these effects on progenitor cells, mediating beneficial effects on atherosclerosis, CXCL12/CXCR4 may also influence disease development by influencing various atherosclerosisrelated cells. This is especially interesting, since CXCR4 is expressed on basically every cell-type related to atherogenesis, like monocytes, macrophages, neutrophils, ECs, SMCs, and Tand B-cells (106-110). However, until now there have been no studies directly investigating the causal cell-type-specific effects of CXCL12/CXCR4 in relation to atherosclerosis. Though there are already various studies at least associating this axis with atherogenesis.

For macrophages, it has been shown that oxLDL, also in large amounts present in atherosclerotic lesions, upregulated CXCR4 expression which could contribute to macrophage migration (111). The CXCL12/CXCR4 signaling in macrophages was also implicated in macropinocytosis, indicating a possible influence on lipid accumulation in these cells (112). Furthermore, it has also been associated with neutrophils as it regulates the release of neutrophils from the bone marrow (113). Not only the release is mediated by this axis, but also the clearance of circulating neutrophils as senescent neutrophils shows increased expression levels of CXCR4-mediating effective clearance (114). By contrast, activated neutrophils downregulate CXCR4 levels, leading to postponed clearance (97). Treatment of $\mathrm{ApoE}^{-/-}$mice with AMD3100 resulted in an increased neutrophil mobilization, thereby increasing atherosclerotic lesion areas $(44,45)$. ECs also release more CXCL12 after oxLDL stimulation (115). Additionally, laminar shear stress appeared to influence CXCR4 expression, where high shear suppresses CXCR4 expression (116). CXCL12 can also increase vascular endothelial growth factor (VEGF) expression in ECs, which promotes angiogenesis (117). As angiogenesis is inducing a more vulnerable plaque phenotype, CXCL12 could have lesion destabilization effects. Chemotaxis of both T- and B-cell is also positively influenced by CXCL12/CXCR4 (118-121). Besides CXCL12/CXC4 effect on all these different cell-types, expression of CXCL12/CXCR4 has also been shown on platelets $(6,122)$. Platelets are the first to arrive at a site of vascular injury, where its glycoproteins Ib and IIb/IIIa engage surface molecules on the ECs, contributing to endothelial activation (4). Platelets also produce and store CXCL12 in their $\alpha$-granules. Upon release, platelet-derived CXCL12 has been implicated in cell adhesion and chemotaxis (123). Furthermore, CXCL12 is able to induce platelet aggregation, a crucial step in thrombus formation after atherosclerotic plaque rupture (6). Platelets also express the receptor CXCR4, and blocking studies indicated that this receptor is crucially involved in the aggregation effects of CXCL12 (6). Additionally, CXCL12 is able to stimulate platelet migration and transmigration (124). Together, these results show that CXCL12/CXCR4 have interactions with many cells that are relevant in atherosclerosis and is thereby modulating atherosclerosis development. Recently, also a role for ACKR3 in atherosclerosis development has been described, showing that activation of ACKR3 by a synthetic ligand reduced lesion formation and ameliorated hyperlipidemia. ACKR3 seemed to play an important role in the regulation of blood cholesterol levels, by promoting VLDL uptake in adipose tissue (125).

\section{CXCL12 in Atherosclerosis-Related Pathologies}

As previously described, atherosclerotic plaques eventually, either block an artery by growth or by rupture and subsequent thrombus formation. The result is ischemia in downstream tissues. One of the most common places for this to occur is in the heart, resulting in a MI. It is known that hypoxia results in an upregulation of CXCL12 and CXCR4 (126). Various studies have revealed a 
protective role for CXCL12/CXCR4 signaling after MI through survival effects on resident cardiomyocytes and recruitment of protective circulating cells (97). Direct injection of CXCL12, for example, reduced myocardial infarct size after ischemia, which was associated with increased neo-angiogenesis (127). Recruitment of progenitor cells was crucial for this improved vessel growth (128). Supporting a role for CXCL12/CXCR4 in MI are studies using AMD3100, an antagonist for CXCR4. However, results from these studies are quite contradictory. A study using a single injection of AMD3100 showed improved cardiac function and enhanced progenitor cell accumulation and neovascularization $(129,130)$. However, more chronic administration of AMD3100 showed reduced incorporation of progenitor cells and cardiac outcome after MI (131).

CXCL12/CXCR4 has also been shown to play a role in vascular restenosis. The main treatment of choice after arterial blockage is percutaneous coronary intervention, where a stent is placed at the site of lesion development. However, neointimal hyperplasia often causes restenosis of these stents mainly driven by SMCs, thereby again occluding the artery. Systemic treatment of mice that underwent wire-induced arterial injury with CXCL12 or CXCR4 antagonists showed clear reductions of neointimal size and SMC content $(132,133)$. This reduced SMC content was caused by a reduction in progenitor mobilization toward the site of injury $(132,133)$. Additionally, CXCR4 blockage reduced cellular proliferation at sites of neointimal lesions (134). A significant decrease in EPC mobilization was recently also observed using genetic EC-specific knockout of CXCR4, although mice showed larger neointimal lesions consisting of more inflammatory macrophages, but less SMCs (135).

\section{Human and Clinical Implications for CXCL12}

Genome-wide association studies showed clear associations of CXCL12 with CVD (5) (Table 1). Previously, it was already shown that vascular cells express high levels of CXCL12 in human atherosclerotic lesions, but not in normal vessels (6). Various human studies supported the idea that CXCL12 is a potential regulatory agent in atherosclerosis. A study, comparing plasma CXCL12 levels of angina patients with healthy controls, showed decreased levels of CXCL12 in the patient group (9). Patients with unstable angina had even lower CXCL12 levels than those with stable angina. Additionally, these patients showed decreased surface protein expression of CXCR4 in peripheral blood mononuclear cells, while the RNA expression was increased probably as compensatory mechanism (9). Combined, this study suggests anti-atherogenic properties of CXCL12. In contrast, another study observed significantly increased CXCL12 expression on platelets of stable angina patients, compared to healthy controls. Plasma CXCL12 levels also correlated with platelet activation (7), suggesting a more atherogenic and pro-thrombotic role for CXCL12. In addition, both CXCR4 and ACKR3 are more highly expressed on platelets from CVD patients, compared to healthy controls (8). It is suggested that platelet-derived CXCL12 expression occurs relatively fast after vessel injury, being as early as $30 \mathrm{~min}$ (136). Currently, used biomarkers for acute coronary syndrome, like troponin-I are much slower. Therefore determination of CXCL12 might be very useful as early additional biomarker (11).
Recently, it was shown that CXCL12 is also associated with heart failure (137), and that plasma CXCL12 levels are even superior to traditional risk factors in predicting adverse cardiovascular outcomes (10). Although there are still some contradictory clinical results, it is clear that CXCL12 does play a role in atherosclerosis and CVD.

\section{Macrophage Migration-Inhibitory Factor}

\section{Ligand/Receptor Characteristics}

Discovered almost 50 years ago, macrophage MIF was one of the first cytokines to be identified (138). MIF is part of the CLF chemokine family, as it is missing the typical N-terminal cysteines (139). The name is derived from its discovery as MIF-containing supernatant showed to be inhibitory for macrophage migration (140). At first, T cells were thought to be the main cellular source of MIF. However, since its discovery, expression of MIF has also been shown in other immunity cells like monocytes, macrophages, neutrophils, dendritic cells, and B cells $(13,141-146)$. In contrast to many other chemokines, MIF is constitutively expressed and deposited in intracellular storages. Thus, upon stimulation, MIF release does not require de novo synthesis (138). It has already been well described that MIF can directly or indirectly stimulate a large variety of pro-inflammatory molecules, including various cytokines and nitric oxide. Additionally, MIF was shown to override the immunosuppressive effects of glucocorticoids (147). MIF has been implicated in various acute and chronic inflammatory diseases, like sepsis, rheumatoid arthritis, and cancer (148-150).

The first receptor identified for MIF was CD74, the membraneexpressed form of invariant chain and an MHC class II chaperone (151). However, besides its role in antigenic peptide loading, CD74 can also be expressed in the absence of the MHC class II protein, thus exerting functions as membrane receptor (152). MIF binds with high affinity to CD74, although CD74 by itself is not able to induce intracellular signaling. Therefore, it requires the recruitment of signaling-competent co-receptors. CD44 was the first described co-receptor of CD74, able to mediate signal transduction (153). CXCR2 and CXCR4 have also been described as co-receptors for CD74 $(154,155)$. The combination of CD74 with CD44 has been linked with MIF's pro-inflammatory and anti-apoptotic functions by the activation of MAPKs $(153,156)$. CD74/CXCR2 complexes have been shown to be involved in MIF-mediated monocyte chemotaxis and arrest. In line, a role for CD74 in atherogenesis has been identified (157).

CXCR4 has already been discussed previously as receptor for CXCL12. It has been found, in monocytes, T cells and fibroblasts, that CXCR4 can also form heterodimers with CD74 and induce Akt signaling (155). CXCR4 has mainly been shown as the receptor responsible for MIF-induced T cell recruitment (154). Finally, CXCR2 has been described as important receptor for MIF. MIF/ CXCR2 interaction mainly triggered the recruitment and arrest of monocytes. Furthermore, MIF/CXCR2 has been implicated in integrin activation, an important step in leukocyte recruitment. Recently, ACKR3 on platelets has also been described as receptor for MIF, although it is still not clear whether this is a direct ligand-receptor interaction or indirect interaction via receptor heterodimerization such as CXCR2/ACKR3 (158). 


\section{MIF in Atherosclerosis}

Hyperlipidemia is one of the hallmarks of atherogenesis. It was shown that upon hyperlipidemia, MIF expression is greatly enhanced in cells crucial for atherosclerosis development, like ECs, SMCs, monocytes, and T cells (13, 159, 160). As atherosclerotic lesions progressed, MIF expression was even further increased. Combined, these data clearly implicate MIF not only in atherosclerotic lesion development, but also in plaque destabilization.

Leukocyte recruitment into atherosclerotic plaques is one of the most important processes during lesion development. In vitro adhesion assays under flow clearly showed an increased monocyte arrest of monocytes to aortic ECs upon MIF incubation (161). This was confirmed by using MIF neutralizing antibodies, which blocked the observed effects. Additionally, using small interfering RNA to inhibit endothelial MIF production, it was observed that MIF deficiency resulted in a decreased expression of E-selectin, ICAM-1, VCAM1, IL-8, and MCP-1, all important mediators of leukocyte recruitment (162). Bernhagen et al. clearly showed that MIF can also more directly trigger monocyte, neutrophil, and $\mathrm{T}$ cell arrest and chemotaxis in an integrin-dependent manner (154). They further implicated the receptors for MIF in this process, since the integrin activation resulted in the triggering of $\mathrm{G}_{\alpha \mathrm{i}}$ activities of CXCR2 in monocytes and neutrophils and of CXCR4 in T cells. Additionally, CD74 also contributes to monocyte recruitment by interacting with CXCR2 (154).

Various functional animal studies confirmed the role of MIF in atherosclerosis development. MIF-deficient mice on an atherogenic background showed significantly reduced lipid deposition and lesion size compared to control animals (163). This was accompanied by a decreased lesion cell proliferation, especially of SMCs. Additionally, neutralizing MIF with specific monoclonal antibodies showed a reduced lesion size and especially reduced intimal inflammation (160). MIF blockage was even showed to induce regression of already established atherosclerotic lesions (154). Additionally, MIF stimulates the uptake of oxLDL by macrophages and is associated with the expression of proteases (163), which can contribute to the lesion destabilization properties of MIF. Recently, also an important role for platelet-derived MIF was described (164). MIF was even shown to have a stronger chemotactic activity than CXCL12 and substantially contributed to monocyte adhesion to an endothelial layer. Although in contrast to CXCL12 secretion, MIF secretion from platelets was much slower and did not enhance platelet activation (164).

Studies with CXCR2-deficient mice also identified important roles for CXCR2 in monocyte recruitment into atherosclerotic lesions, showing reduced lesion size and lesional macrophage content (165). In atherosclerosis studies with other CXCR2 ligands, like CXCL1 and CXCL8, deficiencies did not exceed half the effect of the receptor deficiency on atherogenesis, suggesting the presence of other ligands that play a crucial role (166). In 2007, MIF was identified as ligand for CXCR2 with pro-atherogenic capacities (154). Combined, all these studies clearly identify MIF and its receptors as an important mediator of leukocyte recruitment and atherosclerosis development.

\section{MIF in Atherosclerosis-Related Pathologies}

As described earlier, restenosis occurs frequently after stent implantation, leading to early stent failure. Carotid artery wire injury methods are often used to model this disease, characterized by neointimal hyperplasia driven by SMC proliferation. Carotid artery injury resulted in a fast induction of MIF expression in SMCs and later on also in foam cell formation $(161,167)$. To determine the causal role of MIF in neointimal hyperplasia, antibody-mediated MIF blockage has been used in various studies. MIF blockage indeed resulted in a decreased medial cell proliferation, enhanced apoptosis, and smaller inflammatory cell content (167). Another study also showed a decreased macrophage content and foam cell formation upon MIF blockage (161). This was accompanied by an increase in SMC and collagen content in the neointimal areas, suggesting a more stable phenotype after MIF blockage (168).

Various studies also describe MIF as a protective factor in MI-ischemia-reperfusion injury (63). However, recently it has been shown that this effect is dependent on the cellular source of MIF. Global MIF deficiency protects the heart from post-infarct cardiac rupture and remodeling, by suppressing the leukocyte infiltration and thus inflammation (169). However, leukocytederived MIF exerts opposing effects by promoting the inflammatory response after MI (169). These compartmentalized and opposing effects are shown to be mediated by CXCR2 (170).

\section{Human and Clinical Implications for MIF}

In humans, MIF has been shown to be abundantly produced by various cells in different stages of plaque development, indicating an important role for MIF in early plaque development but also in more advanced complicated lesions (13) (Table 1). Later, it was observed in human lesions that MIF plays a more important role in vulnerable lesions, compared to fibrous lesions. MIF was associated with the weakening of the fibrous cap, by inducing MMP-1 expression and activity in SMCs (14). CVD patients, more particularly patients with acute coronary syndromes also showed enhanced plasma MIF levels. Plasma MIF levels from these patients were associated with inflammatory markers like CRP and IL-6, but also with the cardiac necrosis marker troponin-I (15). High plasma MIF levels have also been identified as an independent risk factor for future coronary events in patients with CVD and impaired glucose tolerance or type 2 diabetes mellitus (16). Lately, the Grem1/MIF ratio has been identified as novel marker associated with CVD and the grade of plaque stability. Grem 1 was discovered as an endogenous inhibitor of MIF (17). Furthermore, human epidemiological studies supported a pro-atherogenic role of MIF, by showing that a MIF single nucleotide polymorphism was associated with an enhanced risk for MI (12). A large group of MI patients also had elevated MIF plasma levels and these levels were predictive of final infarct size and the extent of cardiac remodeling (18). Elevated MIF levels in these patients were already observed after 4 to $6 \mathrm{~h}$ after acute MI, which could be very beneficial for the early detection of MI since current used markers or only elevated after 6 to $12 \mathrm{~h}$ post-MI (18).

There are already several MIF inhibitors developed, which show protective effects in various inflammatory models (168). 
Another attractive therapeutic strategy would be to directly target the receptors for MIF, CXCR2, or CXCR4, or to manipulate the ligand-receptor interaction. However, more research is first needed to fully elucidate these precise interactions. Although MIF seems like a suitable target for therapy and biomarker in patients, the use of MIF as biomarker in healthy persons should be approached with caution. Prospective data suggest that the relation between MIF and the risk of MI or death due to CVD in humans without prior history of CVD is not very strong (19).

\section{CXCL12 and MIF Side by Side}

Both CXCL12 and MIF play an important role in the development of CVDs. However, besides some common effects both chemokines vary functionally from each other, partly mediated by differential receptor usage (Figure 1). An important common function that both chemokines have is the induction of leukocyte chemotaxis and arrest. However, as MIF seems to have more pro-atherosclerotic effects, CXCL12 may have a protective function, although results are still contradictory at some level and future research should further elucidate the exact role of these chemokines in atherosclerosis. Regarding vascular restenosis the effects of CXCL12 and MIF are more equal, since blockade studies showed that inhibition of either CXCL12 or MIF has beneficial outcomes on neointimal hyperplasia. Additionally, blockage of CXCR4, the receptor for both CXCL12 and MIF, has been shown to reduce neointimal formation. Furthermore, both CXCL12 and MIF play a protective role in MI-ischemia-reperfusion injury. For CXCL12, this beneficial effect upon systemic CXCL12 injection was associated with increased recruitment of progenitor cells and neo-angiogenesis. However, the beneficial effects of MIF seem to be cellular source dependent as global MIF deficiency reduced inflammation, while leukocyte-derived MIF promoted the inflammatory response after MI.

\section{References}

1. Dahlof B. Cardiovascular disease risk factors: epidemiology and risk assessment. Am J Cardiol (2010) 105(1 Suppl):3A-9A. doi:10.1016/j. amjcard.2009.10.007

2. Lloyd-Jones DM. Cardiovascular risk prediction: basic concepts, current status, and future directions. Circulation (2010) 121(15):1768-77. doi:10.1161/ CIRCULATIONAHA.109.849166

3. Go AS, Mozaffarian D, Roger VL, Benjamin EJ, Berry JD, Borden WB, et al. Heart disease and stroke statistics - 2013 update: a report from the American heart association. Circulation (2013) 127(1):e6-245. doi:10.1161/ CIR.0b013e318282ab8f

4. Hansson GK. Inflammation, atherosclerosis, and coronary artery disease. $N$ Engl J Med (2005) 352(16):1685-95. doi:10.1056/NEJMra043430

5. Farouk SS, Rader DJ, Reilly MP, Mehta NN. CXCL12: a new player in coronary disease identified through human genetics. Trends Cardiovasc Med (2010) 20(6):204-9. doi:10.1016/j.tcm.2011.08.002

6. Abi-Younes S, Sauty A, Mach F, Sukhova GK, Libby P, Luster AD. The stromal cell-derived factor-1 chemokine is a potent platelet agonist highly expressed in atherosclerotic plaques. Circ Res (2000) 86(2):131-8. doi:10.1161/01.RES.86.2.131

7. Stellos K, Bigalke B, Langer H, Geisler T, Schad A, Kogel A, et al. Expression of stromal-cell-derived factor-1 on circulating platelets is increased in patients with acute coronary syndrome and correlates with the number of CD34+ progenitor cells. Eur Heart J (2009) 30(5):584-93. doi:10.1093/eurheartj/ ehn566

\section{Concluding Remarks}

It has already been well described that chemokines play an important role in inflammation, atherosclerosis, and CVD. However, the exact involvement of all these chemokines remains very complicated and as research in this area advances, current ideas and dogmas may still change. In the recent years, more data are accumulating pointing toward crucial roles of these chemokines in atherosclerosis and CVD. There have also already been some studies describing the ligand-receptor interactions and the involvement of the receptors, CXCR2, CXCR4, and ACKR3 in different pathologies, although also in this respect further research is needed to identify cell-type-specific effects of CXCR4 for example, but also to clarify the triggered intracellular signaling. Due to the complexity of this chemokine system, one should be very cautious with designing chemokine-based therapeutics, since unwanted side effects may occur very easily. Therefore very specific targeting approaches, like antibodies or inhibitors, are needed to isolate a specific ligand-receptor interaction, perhaps even at a specific cell type.

\section{Author Contributions}

EV: drafting the manuscript; YD: concept and design, critical revision; CW: concept and design, critical revision.

\section{Acknowledgments}

This work was supported by the DeutscheForschungsgemeinschaft (SFB 1123-A1), the German Centre for Cardiovascular Research (MHA VD 1.2), the European Research Council (ERC AdG number 249929), the German Federal Ministry of Education and Research (grant number 01KU1213A), and the Leducq Transatlantic Network CVGene (Fx).

8. Rath D, Chatterjee M, Borst O, Muller K, Stellos K, Mack AF, et al. Expression of stromal cell-derived factor-1 receptors CXCR4 and CXCR7 on circulating platelets of patients with acute coronary syndrome and association with left ventricular functional recovery. Eur Heart J (2014) 35(6):386-94. doi:10.1093/ eurheartj/eht 448

9. Damas JK, Waehre T, Yndestad A, Ueland T, Muller F, Eiken HG, et al. Stromal cell-derived factor-1alpha in unstable angina: potential antiinflammatory and matrix-stabilizing effects. Circulation (2002) 106(1):36-42. doi:10.1161/01.CIR.0000020001.09990.90

10. Ghasemzadeh N, Hritani AW, De Staercke C, Eapen DJ, Veledar E, Al Kassem H, et al. Plasma stromal cell-derived factor 1alpha/CXCL12 level predicts long-term adverse cardiovascular outcomes in patients with coronary artery disease. Atherosclerosis (2015) 238(1):113-8. doi:10.1016/j. atherosclerosis.2014.10.094

11. Wurster T, Stellos K, Haap M, Seizer P, Geisler T, Otton J, et al. Platelet expression of stromal-cell-derived factor-1 (SDF-1): an indicator for ACS? Int J Cardiol (2013) 164(1):111-5. doi:10.1016/j.ijcard.2011.06.082

12. Tereshchenko IP, Petrkova J, Mrazek F, Lukl J, Maksimov VN, Romaschenko AG, et al. The macrophage migration inhibitory factor (MIF) gene polymorphism in Czech and Russian patients with myocardial infarction. Clin Chim Acta (2009) 402(1-2):199-202. doi:10.1016/j.cca.2008.12.034

13. Burger-Kentischer A, Goebel H, Seiler R, Fraedrich G, Schaefer HE, Dimmeler S, et al. Expression of macrophage migration inhibitory factor in different stages of human atherosclerosis. Circulation (2002) 105(13):1561-6. doi:10.1161/01.CIR.0000012942.49244.82 
14. Kong YZ, Huang XR, Ouyang X, Tan JJ, Fingerle-Rowson G, Bacher M, et al. Evidence for vascular macrophage migration inhibitory factor in destabilization of human atherosclerotic plaques. Cardiovasc Res (2005) 65(1):272-82. doi:10.1016/j.cardiores.2004.09.020

15. Müller II, Müller KA, Schönleber H, Karathanos A, Schneider M, Jorbenadze $\mathrm{R}$, et al. Macrophage migration inhibitory factor is enhanced in acute coronary syndromes and is associated with the inflammatory response. PLoS One (2012) 7(6):e38376. doi:10.1371/journal.pone.0038376

16. Makino A, Nakamura T, Hirano M, Kitta Y, Sano K, Kobayashi T, et al. High plasma levels of macrophage migration inhibitory factor are associated with adverse long-term outcome in patients with stable coronary artery disease and impaired glucose tolerance or type 2 diabetes mellitus. Atherosclerosis (2010) 213(2):573-8. doi:10.1016/j.atherosclerosis.2010.09.004

17. MüllerII, Müller KA, Karathanos A, SchönleberH, Rath D, VogelS, et al.Impact of counterbalance between macrophage migration inhibitory factor and its inhibitor gremlin-1 in patients with coronary artery disease. Atherosclerosis (2014) 237(2):426-32. doi:10.1016/j.atherosclerosis.2014.09.010

18. Chan W, White DA, Wang XY, Bai RF, Liu Y, Yu HY, et al. Macrophage migration inhibitory factor for the early prediction of infarct size. J Am Heart Assoc (2013) 2(5):e000226. doi:10.1161/JAHA.113.000226

19. Boekholdt SM, Peters RJ, Day NE, Luben R, Bingham SA, Wareham NJ, et al. Macrophage migration inhibitory factor and the risk of myocardial infarction or death due to coronary artery disease in adults without prior myocardial infarction or stroke: the EPIC-Norfolk prospective population study. Am J Med (2004) 117(6):390-7. doi:10.1016/j.amjmed.2004.04.010

20. Rosengren A, Hawken S, Ounpuu S, Sliwa K, Zubaid M, Almahmeed WA, et al. Association of psychosocial risk factors with risk of acute myocardial infarction in 11119 cases and 13648 controls from 52 countries (the INTERHEART study): case-control study. Lancet (2004) 364(9438):953-62. doi:10.1016/S0140-6736(04)17019-0

21. Yusuf S, Hawken S, Ounpuu S, Dans T, Avezum A, Lanas F, et al. Effect of potentially modifiable risk factors associated with myocardial infarction in 52 countries (the INTERHEART study): case-control study. Lancet (2004) 364(9438):937-52. doi:10.1016/S0140-6736(04)17018-9

22. Nahrendorf M, Swirski FK. Lifestyle effects on hematopoiesis and atherosclerosis. Circ Res (2015) 116(5):884-94. doi:10.1161/CIRCRESAHA.116.303550

23. Kovacic S, Bakran M. Genetic susceptibility to atherosclerosis. Stroke Res Treat (2012) 2012:362941. doi:10.1155/2012/362941

24. Zarins CK, Giddens DP, Bharadvaj BK, Sottiurai VS, Mabon RF, Glagov S. Carotid bifurcation atherosclerosis. Quantitative correlation of plaque localization with flow velocity profiles and wall shear stress. Circ Res (1983) 53(4):502-14. doi:10.1161/01.RES.53.4.502

25. Williams KJ, Tabas I. The response-to-retention hypothesis of early atherogenesis. Arterioscler Thromb Vasc Biol (1995) 15(5):551-61. doi:10.1161/01. ATV.15.5.551

26. Hansson GK, Hermansson A. The immune system in atherosclerosis. Nat Immunol (2011) 12(3):204-12. doi:10.1038/ni.2001

27. Glass CK, Witztum JL. Atherosclerosis. the road ahead. Cell (2001) 104(4):503-16. doi:10.1016/S0092-8674(01)00238-0

28. Kunjathoor VV, Febbraio M, Podrez EA, Moore KJ, Andersson L, Koehn S, et al. Scavenger receptors class A-I/II and CD36 are the principal receptors responsible for the uptake of modified low density lipoprotein leading to lipid loading in macrophages. J Biol Chem (2002) 277(51):49982-8. doi:10.1074/ jbc.M209649200

29. Pluddemann A, Neyen C, Gordon S. Macrophage scavenger receptors and host-derived ligands. Methods (2007) 43(3):207-17. doi:10.1016/j. ymeth.2007.06.004

30. Maxfield FR, Tabas I. Role of cholesterol and lipid organization in disease. Nature (2005) 438(7068):612-21. doi:10.1038/nature04399

31. Brown MS, Ho YK, Goldstein JL. The cholesteryl ester cycle in macrophage foam cells. Continual hydrolysis and re-esterification of cytoplasmic cholesteryl esters. J Biol Chem (1980) 255(19):9344-52.

32. Tall AR, Yvan-Charvet L, Terasaka N, Pagler T, Wang N. HDL, ABC transporters, and cholesterol efflux: implications for the treatment of atherosclerosis. Cell Metab (2008) 7(5):365-75. doi:10.1016/j.cmet.2008.03.001

33. Wang J, Tong C, Yan X, Yeung E, Gandavadi S, Hare AA, et al. Limiting cardiac ischemic injury by pharmacological augmentation of macrophage migration inhibitoryfactor-AMP-activated proteinkinasesignaltransduction.Circulation (2013) 128(3):225-36. doi:10.1161/CIRCULATIONAHA.112.000862
34. Murphy AJ, Dragoljevic D, Tall AR. Cholesterol efflux pathways regulate myelopoiesis: a potential link to altered macrophage function in atherosclerosis. Front Immunol (2014) 5:490. doi:10.3389/fimmu.2014.00490

35. McLaren JE, Michael DR, Ashlin TG, Ramji DP. Cytokines, macrophage lipid metabolism and foam cells: implications for cardiovascular disease therapy. Prog Lipid Res (2011) 50(4):331-47. doi:10.1016/j.plipres.2011.04.002

36. Passlick B, Flieger D, Ziegler-Heitbrock HW. Identification and characterization of a novel monocyte subpopulation in human peripheral blood. Blood (1989) 74(7):2527-34.

37. Gautier EL, Jakubzick C, Randolph GJ. Regulation of the migration and survival of monocyte subsets by chemokine receptors and its relevance to atherosclerosis. Arterioscler Thromb Vasc Biol (2009) 29(10):1412-8. doi:10.1161/ATVBAHA.108.180505

38. Wong KL, Tai JJ, Wong WC, Han H, Sem X, Yeap WH, et al. Gene expression profiling reveals the defining features of the classical, intermediate, and nonclassical human monocyte subsets. Blood (2011) 118(5):e16-31. doi:10.1182/ blood-2010-12-326355

39. Zlotnik A, Yoshie O. Chemokines: a new classification system and their role in immunity. Immunity (2000) 12(2):121-7. doi:10.1016/\$1074-7613(00) 80165-X

40. Geissmann F, Jung S, Littman DR. Blood monocytes consist of two principal subsets with distinct migratory properties. Immunity (2003) 19(1):71-82. doi:10.1016/S1074-7613(03)00174-2

41. Woollard KJ, Geissmann F. Monocytes in atherosclerosis: subsets and functions. Nat Rev Cardiol (2010) 7(2):77-86. doi:10.1038/nrcardio.2009.228

42. Ziegler-Heitbrock L, Ancuta P, Crowe S, Dalod M, Grau V, Hart DN, et al. Nomenclature of monocytes and dendritic cells in blood. Blood (2010) 116(16):e74-80. doi:10.1182/blood-2010-02-258558

43. Sunderkotter C, Nikolic T, Dillon MJ, Van Rooijen N, Stehling M, Drevets DA, et al. Subpopulations of mouse blood monocytes differ in maturation stage and inflammatory response. J Immunol (2004) 172(7):4410-7. doi:10.4049/ jimmunol.172.7.4410

44. Zernecke A, Bot I, Djalali-Talab Y, Shagdarsuren E, Bidzhekov K, Meiler S, et al. Protective role of CXC receptor 4/CXC ligand 12 unveils the importance of neutrophils in atherosclerosis. Circ Res (2008) 102(2):209-17. doi:10.1161/ CIRCRESAHA.107.160697

45. Zernecke A, Shagdarsuren E, Weber C. Chemokines in atherosclerosis: an update. Arterioscler Thromb Vasc Biol (2008) 28(11):1897-908. doi:10.1161/ ATVBAHA.107.161174

46. Swirski FK, Libby P, Aikawa E, Alcaide P, Luscinskas FW, Weissleder R, et al. Ly-6Chi monocytes dominate hypercholesterolemia-associated monocytosis and give rise to macrophages in atheromata. J Clin Invest (2007) 117(1):195205. doi:10.1172/JCI29950

47. Moore KJ, Sheedy FJ, Fisher EA. Macrophages in atherosclerosis: a dynamic balance. Nat Rev Immunol (2013) 13(10):709-21. doi:10.1038/nri3520

48. Barreiro O, Yanez-Mo M, Serrador JM, Montoya MC, Vicente-Manzanares $\mathrm{M}$, Tejedor R, et al. Dynamic interaction of VCAM-1 and ICAM-1 with moesin and ezrin in a novel endothelial docking structure for adherent leukocytes. J Cell Biol (2002) 157(7):1233-45. doi:10.1083/jcb.200112126

49. Gerhardt T, Ley K. Monocyte trafficking across the vessel wall. Cardiovasc Res (2015) pii:cvv147. doi:10.1093/cvr/cvv147

50. Weber C, Noels H. Atherosclerosis: current pathogenesis and therapeutic options. Nat Med (2011) 17(11):1410-22. doi:10.1038/nm.2538

51. Weber C, Fraemohs L, Dejana E. The role of junctional adhesion molecules in vascular inflammation. Nat Rev Immunol (2007) 7(6):467-77. doi:10.1038/ nri2096

52. Carman CV, Springer TA. A transmigratory cup in leukocyte diapedesis both through individual vascular endothelial cells and between them. J Cell Biol (2004) 167(2):377-88. doi:10.1083/jcb.200404129

53. Johnson JL, Newby AC. Macrophage heterogeneity in atherosclerotic plaques. Curr Opin Lipidol (2009) 20(5):370-8. doi:10.1097/MOL.0b013e3283309848

54. Shimada K. Immune system and atherosclerotic disease: heterogeneity of leukocyte subsets participating in the pathogenesis of atherosclerosis. Circ J (2009) 73(6):994-1001. doi:10.1253/circj.CJ-09-0277

55. Wolfs IM, Donners MM, de Winther MP. Differentiation factors and cytokines in the atherosclerotic plaque micro-environment as a trigger for macrophage polarisation. Thromb Haemost (2011) 106(5):763-71. doi:10.1160/TH11-05-0320

56. Tabas I. Macrophage death and defective inflammation resolution in atherosclerosis. Nat Rev Immunol (2010) 10(1):36-46. doi:10.1038/nri2675 
57. Tabas I, Ron D. Integrating the mechanisms of apoptosis induced by endoplasmic reticulum stress. Nat Cell Biol (2011) 13(3):184-90. doi:10.1038/ncb0311-184

58. Virmani R, Burke AP, Kolodgie FD, Farb A. Vulnerable plaque: the pathology of unstable coronary lesions. J Interv Cardiol (2002) 15(6):439-46. doi:10.111 1/j.1540-8183.2002.tb01087.x

59. Moore KJ, Tabas I. Macrophages in the pathogenesis of atherosclerosis. Cell (2011) 145(3):341-55. doi:10.1016/j.cell.2011.04.005

60. Lusis AJ. Atherosclerosis. Nature (2000) 407(6801):233-41. doi:10.1038/ 35025203

61. Blanchet X, Langer M, Weber C, Koenen RR, von Hundelshausen P. Touch of chemokines. Front Immunol (2012) 3:175. doi:10.3389/fimmu.2012.00175

62. Rajagopalan L, Rajarathnam K. Structural basis of chemokine receptor function - a model for binding affinity and ligand selectivity. Biosci Rep (2006) 26(5):325-39. doi:10.1007/s10540-006-9025-9

63. Asare Y, Schmitt M, Bernhagen J. The vascular biology of macrophage migration inhibitory factor (MIF). Expression and effects in inflammation, atherogenesis and angiogenesis. Thromb Haemost (2013) 109(3):391-8. doi:10.1160/TH12-11-0831

64. Bachelerie F, Ben-Baruch A, Burkhardt AM, Combadiere C, Farber JM, Graham GJ, et al. International union of basic and clinical pharmacology. [corrected]. LXXXIX. Update on the extended family of chemokine receptors and introducing a new nomenclature for atypical chemokine receptors. Pharmacol Rev (2014) 66(1):1-79. doi:10.1124/pr.113.007724

65. Zernecke A, Weber C. Chemokines in atherosclerosis: proceedings resumed. Arterioscler Thromb Vasc Biol (2014) 34(4):742-50. doi:10.1161/ ATVBAHA.113.301655

66. Zhou Z, Subramanian P, Sevilmis G, Globke B, Soehnlein O, Karshovska E, et al. Lipoprotein-derived lysophosphatidic acid promotes atherosclerosis by releasing CXCL1 from the endothelium. Cell Metab (2011) 13(5):592-600. doi:10.1016/j.cmet.2011.02.016

67. Drechsler M, Megens RT, van Zandvoort M, Weber C, Soehnlein O. Hyperlipidemia-triggeredneutrophiliapromotesearlyatherosclerosis.Circulation (2010) 122(18):1837-45. doi:10.1161/CIRCULATIONAHA.110.961714

68. Soehnlein O, Drechsler M, Doring Y, Lievens D, Hartwig H, Kemmerich $\mathrm{K}$, et al. Distinct functions of chemokine receptor axes in the atherogenic mobilization and recruitment of classical monocytes. EMBO Mol Med (2013) 5(3):471-81. doi:10.1002/emmm.201201717

69. Sheikine Y, Hansson GK. Chemokines and atherosclerosis. Ann Med (2004) 36(2):98-118. doi:10.1080/07853890310019961

70. Tacke F, Alvarez D, Kaplan TJ, Jakubzick C, Spanbroek R, Llodra J, et al. Monocyte subsets differentially employ CCR2, CCR5, and CX3CR1 to accumulate within atherosclerotic plaques. J Clin Invest (2007) 117(1):185-94. doi:10.1172/JCI28549

71. Boring L, Gosling J, Cleary M, Charo IF. Decreased lesion formation in CCR2-/- mice reveals a role for chemokines in the initiation of atherosclerosis. Nature (1998) 394(6696):894-7. doi:10.1038/29788

72. Serbina NV, Pamer EG. Monocyte emigration from bone marrow during bacterial infection requires signals mediated by chemokine receptor CCR2. Nat Immunol (2006) 7(3):311-7. doi:10.1038/ni1309

73. Landsman L, Bar-On L, Zernecke A, Kim KW, Krauthgamer R, Shagdarsuren E, et al. CX3CR1 is required for monocyte homeostasis and atherogenesis by promoting cell survival. Blood (2009) 113(4):963-72. doi:10.1182/ blood-2008-07-170787

74. Potteaux S, Combadiere C, Esposito B, Casanova S, Merval R, Ardouin P, et al. Chemokine receptor CCR1 disruption in bone marrow cells enhances atherosclerotic lesion development and inflammation in mice. Mol Med (2005) 11(1-12):16-20. doi:10.2119/2005-00028.Potteaux

75. Braunersreuther V, Zernecke A, Arnaud C, Liehn EA, Steffens S, Shagdarsuren E, et al. Ccr5 but not Ccr1 deficiency reduces development of diet-induced atherosclerosis in mice. Arterioscler Thromb Vasc Biol (2007) 27(2):373-9. doi:10.1161/01.ATV.0000253886.44609.ae

76. Trogan E, Feig JE, Dogan S, Rothblat GH, Angeli V, Tacke F, et al. Gene expression changes in foam cells and the role of chemokine receptor CCR7 during atherosclerosis regression in ApoE-deficient mice. Proc Natl Acad Sci U S A (2006) 103(10):3781-6. doi:10.1073/pnas.0511043103

77. Feig JE, Rong JX, Shamir R, Sanson M, Vengrenyuk Y, Liu J, et al. HDL promotes rapid atherosclerosis regression in mice and alters inflammatory properties of plaque monocyte-derived cells. Proc Natl Acad Sci U S A (2011) 108(17):7166-71. doi:10.1073/pnas.1016086108
78. Feig JE, Shang Y, Rotllan N, Vengrenyuk Y, Wu C, Shamir R, et al. Statins promote the regression of atherosclerosis via activation of the CCR7-dependent emigration pathway in macrophages. PLoS One (2011) 6(12):e28534. doi:10.1371/journal.pone.0028534

79. Luchtefeld M, Grothusen C, Gagalick A, Jagavelu K, Schuett H, Tietge UJ, et al. Chemokine receptor 7 knockout attenuates atherosclerotic plaque development. Circulation (2010) 122(16):1621-8. doi:10.1161/ CIRCULATIONAHA.110.956730

80. Segers D, Lipton JA, Leenen PJ, Cheng C, Tempel D, Pasterkamp G, et al. Atherosclerotic plaque stability is affected by the chemokine CXCL10 in both mice and humans. Int J Inflam (2011) 2011:936109. doi:10.4061/2011/ 936109

81. Murdoch C, Monk PN, Finn A. Cxc chemokine receptor expression on human endothelial cells. Cytokine (1999) 11(9):704-12. doi:10.1006/cyto.1998.0465

82. Fujiwara K, Matsukawa A, Ohkawara S, Takagi K, Yoshinaga M. Functional distinction between CXC chemokines, interleukin-8 (IL-8), and growth related oncogene (GRO)alpha in neutrophil infiltration. Lab Invest (2002) 82(1):15-23. doi:10.1038/labinvest.3780391

83. Ali S, Lazennec G. Chemokines: novel targets for breast cancer metastasis. CancerMetastasisRev (2007) 26(3-4):401-20.doi:10.1007/s10555-007-9073-Z

84. Yu L, Cecil J, Peng SB, Schrementi J, Kovacevic S, Paul D, et al. Identification and expression of novel isoforms of human stromal cell-derived factor 1. Gene (2006) 374:174-9. doi:10.1016/j.gene.2006.02.001

85. Wang JF, Liu ZY, Groopman JE. The alpha-chemokine receptor CXCR4 is expressed on the megakaryocytic lineage from progenitor to platelets and modulates migration and adhesion. Blood (1998) 92(3):756-64.

86. De La Luz Sierra M, Yang F, Narazaki M, Salvucci O, Davis D, Yarchoan $\mathrm{R}$, et al. Differential processing of stromal-derived factor-1alpha and stromal-derived factor-1beta explains functional diversity. Blood (2004) 103(7):2452-9. doi:10.1182/blood-2003-08-2857

87. Teicher BA, Fricker SP. CXCL12 (SDF-1)/CXCR4 pathway in cancer. Clin Cancer Res (2010) 16(11):2927-31. doi:10.1158/1078-0432.CCR-09-2329

88. Orsini MJ, Parent JL, Mundell SJ, Marchese A, Benovic JL. Trafficking of the HIV coreceptor CXCR4. Role of arrestins and identification of residues in the c-terminal tail that mediate receptor internalization. J Biol Chem (1999) 274(43):31076-86. doi:10.1074/jbc.274.43.31076

89. Balabanian K, Lagane B, Infantino S, Chow KY, Harriague J, Moepps B, et al. The chemokine SDF-1/CXCL12 binds to and signals through the orphan receptor RDC1 in T lymphocytes. J Biol Chem (2005) 280(42):35760-6. doi:10.1074/jbc.M508234200

90. Burns JM, Summers BC, Wang Y, Melikian A, Berahovich R, Miao Z, et al. A novel chemokine receptor for SDF-1 and I-TAC involved in cell survival, cell adhesion, and tumor development. J Exp Med (2006) 203(9):2201-13. doi:10.1084/jem.20052144

91. Luker KE, Steele JM, Mihalko LA, Ray P, Luker GD. Constitutive and chemokine-dependent internalization and recycling of CXCR7 in breast cancer cells to degrade chemokine ligands. Oncogene (2010) 29(32):4599-610. doi:10.1038/onc.2010.212

92. Naumann U, Cameroni E, Pruenster M, Mahabaleshwar H, Raz E, Zerwes HG, et al. CXCR7 functions as a scavenger for CXCL12 and CXCL11. PLoS One (2010) 5(2):e9175. doi:10.1371/journal.pone.0009175

93. Sanchez-Alcaniz JA, Haege S, Mueller W, Pla R, Mackay F, Schulz S, et al. Cxcr7 controls neuronal migration by regulating chemokine responsiveness. Neuron (2011) 69(1):77-90. doi:10.1016/j.neuron.2010.12.006

94. Uto-Konomi A, McKibben B, Wirtz J, Sato Y, Takano A, Nanki T, et al. CXCR7 agonists inhibit the function of CXCL12 by down-regulation of CXCR4. Biochem Biophys Res Commun (2013) 431(4):772-6. doi:10.1016/j. bbrc.2013.01.032

95. Kalatskaya I, Berchiche YA, Gravel S, Limberg BJ, Rosenbaum JS, Heveker N. AMD3100 is a CXCR7 ligand with allosteric agonist properties. Mol Pharmacol (2009) 75(5):1240-7. doi:10.1124/mol.108.053389

96. Rajagopal S, Kim J, Ahn S, Craig S, Lam CM, Gerard NP, et al. Beta-arrestin but not $\mathrm{G}$ protein-mediated signaling by the "decoy" receptor CXCR7. Proc Natl Acad Sci U S A (2010) 107(2):628-32. doi:10.1073/pnas.0912852107

97. Döring Y, Pawig L, Weber C, Noels H. The CXCL12/CXCR4 chemokine ligand/receptor axis in cardiovascular disease. Front Physiol (2014) 5:212. doi:10.3389/fphys.2014.00212

98. Guo Y, Hangoc G, Bian H, Pelus LM, Broxmeyer HE. SDF-1/CXCL12 enhances survival and chemotaxis of murine embryonic stem cells and 
production of primitive and definitive hematopoietic progenitor cells. Stem Cells (2005) 23(9):1324-32. doi:10.1634/stemcells.2005-0085

99. Mazo IB, Massberg S, von Andrian UH. Hematopoietic stem and progenitor cell trafficking. Trends Immunol (2011) 32(10):493-503. doi:10.1016/j.it.2011.06.011

100. Dar A, Schajnovitz A, Lapid K, Kalinkovich A, Itkin T, Ludin A, et al. Rapid mobilization of hematopoietic progenitors by AMD3100 and catecholamines is mediated by CXCR4-dependent SDF- 1 release from bone marrow stromal cells. Leukemia (2011) 25(8):1286-96. doi:10.1038/leu.2011.62

101. Du F, Zhou J, Gong R, Huang X, Pansuria M, Virtue A, et al. Endothelial progenitor cells in atherosclerosis. Front Biosci (Landmark Ed) (2012) 17:2327-49. doi:10.2741/4055

102. Merkulova-Rainon T, Broqueres-You D, Kubis N, Silvestre JS, Levy BI. Towards the therapeutic use of vascular smooth muscle progenitor cells. Cardiovasc Res (2012) 95(2):205-14. doi:10.1093/cvr/cvs097

103. Akhtar S, Gremse F, Kiessling F, Weber C, Schober A. CXCL12 promotes the stabilization of atherosclerotic lesions mediated by smooth muscle progenitor cells in apoe-deficient mice. Arterioscler Thromb Vasc Biol (2013) 33(4):679-86. doi:10.1161/ATVBAHA.112.301162

104. Zoll J, Fontaine V, Gourdy P, Barateau V, Vilar J, Leroyer A, et al. Role of human smooth muscle cell progenitors in atherosclerotic plaque development and composition. Cardiovasc Res (2008) 77(3):471-80. doi:10.1093/cvr/cvm034

105. Yao L, Heuser-Baker J, Herlea-Pana O, Iida R, Wang Q, Zou MH, et al. Bone marrow endothelial progenitors augment atherosclerotic plaque regression in a mouse model of plasma lipid lowering. Stem Cells (2012) 30(12):2720-31. doi:10.1002/stem.1256

106. Gupta SK, Lysko PG, Pillarisetti K, Ohlstein E, Stadel JM. Chemokine receptors in human endothelial cells. Functional expression of CXCR4 and its transcriptional regulation by inflammatory cytokines. J Biol Chem (1998) 273(7):4282-7. doi:10.1074/jbc.273.7.4282

107. Murphy PM, Baggiolini M I, Charo F, Hebert CA, Horuk R, Matsushima $\mathrm{K}$, et al. International union of pharmacology. XXII. Nomenclature for chemokine receptors. Pharmacol Rev (2000) 52(1):145-76.

108. Bruhl H, Cohen CD, Linder S, Kretzler M, Schlondorff D, Mack M. Posttranslational and cell type-specific regulation of CXCR4 expression by cytokines. Eur J Immunol (2003) 33(11):3028-37. doi:10.1002/eji.200324163

109. Nie Y, Waite J, Brewer F, Sunshine MJ, Littman DR, Zou YR. The role of CXCR4 in maintaining peripheral B cell compartments and humoral immunity. J Exp Med (2004) 200(9):1145-56. doi:10.1084/jem.20041185

110. Nemenoff RA, Horita H, Ostriker AC, Furgeson SB, Simpson PA, VanPutten $\mathrm{V}$, et al. SDF-1alpha induction in mature smooth muscle cells by inactivation of PTEN is a critical mediator of exacerbated injury-induced neointima formation. Arterioscler Thromb Vasc Biol (2011) 31(6):1300-8. doi:10.1161/ ATVBAHA.111.223701

111. Gupta SK, Pillarisetti K, Lysko PG. Modulation of CXCR4 expression and SDF-1alpha functional activity during differentiation of human monocytes and macrophages. J Leukoc Biol (1999) 66(1):135-43.

112. Tanaka G, Nakase I, Fukuda Y, Masuda R, Oishi S, Shimura K, et al. CXCR4 stimulates macropinocytosis: implications for cellular uptake of arginine-rich cell-penetrating peptides and HIV. Chem Biol (2012) 19(11):1437-46. doi:10.1016/j.chembiol.2012.09.011

113. Eash KJ, Means JM, White DW, Link DC. CXCR4 is a key regulator of neutrophil release from the bone marrow under basal and stress granulopoiesis conditions. Blood (2009) 113(19):4711-9. doi:10.1182/blood-2008-09-177287

114. Martin C, Burdon PC, Bridger G, Gutierrez-Ramos JC, Williams TJ, Rankin SM. Chemokines acting via CXCR2 and CXCR4 control the release of neutrophils from the bone marrow and their return following senescence. Immunity (2003) 19(4):583-93. doi:10.1016/S1074-7613(03)00263-2

115. Li LX, Zhang XF, Bai X, Tong Q. SDF-1 promotes ox-LDL induced vascular smooth muscle cell proliferation. Cell Biol Int (2013) 37(9):988-94. doi:10.1002/cbin.10126

116. Melchionna R, Porcelli D, Mangoni A, Carlini D, Liuzzo G, Spinetti G, et al. Laminar shear stress inhibits CXCR4 expression on endothelial cells: functional consequences for atherogenesis. FASEB J (2005) 19(6):629-31.

117. Saxena A, Fish JE, White MD, Yu S, Smyth JW, Shaw RM, et al. Stromal cell-derived factor-1alpha is cardioprotective after myocardial infarction. Circulation (2008) 117(17):2224-31. doi:10.1161/CIRCULATIONAHA.107.694992

118. Poznansky MC I, Olszak T, Foxall R, Evans RH, Luster AD, Scadden DT. Active movement of T cells away from a chemokine. Nat Med (2000) 6(5):543-8. doi:10.1038/75022
119. Okabe S, Fukuda S, Kim YJ, Niki M, Pelus LM, Ohyashiki K, et al. Stromal cell-derived factor-1alpha/CXCL12-induced chemotaxis of T cells involves activation of the RasGAP-associated docking protein p62Dok-1. Blood (2005) 105(2):474-80. doi:10.1182/blood-2004-03-0843

120. Zhang X, Nakajima T, Goronzy JJ, Weyand CM. Tissue trafficking patterns of effector memory CD4+ T cells in rheumatoid arthritis. Arthritis Rheum (2005) 52(12):3839-49. doi:10.1002/art.21482

121. Klasen C, Ohl K, Sternkopf M, Shachar I, Schmitz C, Heussen N, et al. MIF promotes B cell chemotaxis through the receptors CXCR4 and CD74 and ZAP-70 signaling. JImmunol (2014) 192(11):5273-84. doi:10.4049/ jimmunol.1302209

122. Kowalska MA, Ratajczak J, Hoxie J, Brass LF, Gewirtz A, Poncz M, et al. Megakaryocyte precursors, megakaryocytes and platelets express the HIV co-receptor CXCR4 on their surface: determination of response to stromal-derived factor- 1 by megakaryocytes and platelets. Br J Haematol (1999) 104(2):220-9. doi:10.1046/j.1365-2141.1999.01169.x

123. Chatterjee M, Gawaz M. Platelet-derived CXCL12 (SDF-1alpha): basic mechanisms and clinical implications. J Thromb Haemost (2013) 11(11):1954-67. doi:10.1111/jth.12404

124. Kraemer BF, Borst O, Gehring EM, Schoenberger T, Urban B, Ninci E, et al. PI3 kinase-dependent stimulation of platelet migration by stromal cell-derived factor 1 (SDF-1). J Mol Med (Berl) (2010) 88(12):1277-88. doi:10.1007/ s00109-010-0680-8

125. Li X, Zhu M, Penfold ME, Koenen RR, Thiemann A, Heyll K, et al. Activation of CXCR7 limits atherosclerosis and improves hyperlipidemia by increasing cholesterol uptake in adipose tissue. Circulation (2014) 129(11):1244-53. doi:10.1161/CIRCULATIONAHA.113.006840

126. Lo Celso C, Fleming HE, Wu JW, Zhao CX, Miake-Lye S, Fujisaki J, et al. Live-animal tracking of individual haematopoietic stem/progenitor cells in their niche. Nature (2009) 457(7225):92-6. doi:10.1038/nature07434

127. Hu X, Dai S, Wu WJ, Tan W, Zhu X, Mu J, et al. Stromal cell derived factor-1 alpha confers protection against myocardial ischemia/reperfusion injury: role of the cardiac stromal cell derived factor- 1 alpha CXCR4 axis. Circulation (2007) 116(6):654-63. doi:10.1161/CIRCULATIONAHA.106.672451

128. Askari AT, Unzek S, Popovic ZB, Goldman CK, Forudi F, Kiedrowski M, et al. Effect of stromal-cell-derived factor 1 on stem-cell homing and tissue regeneration in ischaemic cardiomyopathy. Lancet (2003) 362(9385):697-703. doi:10.1016/S0140-6736(03)14232-8

129. Jujo K, Hamada H, Iwakura A, Thorne T, Sekiguchi H, Clarke T, et al. CXCR4 blockade augments bone marrow progenitor cell recruitment to the neovasculature and reduces mortality after myocardial infarction. Proc Natl Acad Sci U S A (2010) 107(24):11008-13. doi:10.1073/pnas.0914248107

130. Jujo K, Ii M, Sekiguchi H, Klyachko E, Misener S, Tanaka T, et al. CXCchemokine receptor 4 antagonist AMD3100 promotes cardiac functional recovery after ischemia/reperfusion injury via endothelial nitric oxide synthase-dependent mechanism. Circulation (2013) 127(1):63-73. doi:10.1161/ CIRCULATIONAHA.112.099242

131. Dai S, Yuan F, Mu J, Li C, Chen N, Guo S, et al. Chronic AMD3100 antagonism of SDF-1alpha-CXCR4 exacerbates cardiac dysfunction and remodeling after myocardial infarction. J Mol Cell Cardiol (2010) 49(4):587-97. doi:10.1016/j. yjmcc.2010.07.010

132. Schober A, Knarren S, Lietz M, Lin EA, Weber C. Crucial role of stromal cell-derived factor-1alpha in neointima formation after vascular injury in apolipoprotein E-deficient mice. Circulation (2003) 108(20):2491-7. doi:10.1161/01.CIR.0000099508.76665.9A

133. Karshovska E, Zagorac D, Zernecke A, Weber C, Schober A. A small molecule CXCR4 antagonist inhibits neointima formation and smooth muscle progenitor cell mobilization after arterial injury. J Thromb Haemost (2008) 6(10):1812-5. doi:10.1111/j.1538-7836.2008.03086.x

134. Olive M, Mellad JA, Beltran LE, Ma M, Cimato T, Noguchi AC, et al. p21Cip1 modulates arterial wound repair through the stromal cell-derived factor-1/ CXCR4 axis in mice. J Clin Invest (2008) 118(6):2050-61. doi:10.1172/ JCI31244

135. Noels H, Zhou B, Tilstam PV, Theelen W, Li X, Pawig L, et al. Deficiency of endothelial CXCR4 reduces reendothelialization and enhances neointimal hyperplasia after vascular injury in atherosclerosis-prone mice. Arterioscler Thromb Vasc Biol (2014) 34(6):1209-20. doi:10.1161/ATVBAHA.113.302878

136. Massberg S, Konrad I, Schürzinger K, Lorenz M, Schneider S, Zohlnhoefer D, et al. Platelets secrete stromal cell-derived factor 1alpha and recruit bone 
marrow-derived progenitor cells to arterial thrombi in vivo. J Exp Med (2006) 203(5):1221-33. doi:10.1084/jem.20051772

137. Subramanian S, Liu C, Aviv A, Ho JE, Courchesne P, Muntendam P, et al. Stromal cell-derived factor 1 as a biomarker of heart failure and mortality risk. Arterioscler Thromb Vasc Biol (2014) 34(9):2100-5. doi:10.1161/ATVBAHA.114.303579

138. Calandra T, Roger T. Macrophage migration inhibitory factor: a regulator of innate immunity. Nat Rev Immunol (2003) 3(10):791-800. doi:10.1038/ nri1200

139. Tillmann S, Bernhagen J, Noels H. Arrest functions of the MIF ligand/receptor axes in atherogenesis. Front Immunol (2013) 4:115. doi:10.3389/fimmu. 2013.00115

140. David JR. Delayed hypersensitivity in vitro: its mediation by cell-free substances formed by lymphoid cell-antigen interaction. Proc Natl Acad Sci U S A (1966) 56(1):72-7. doi:10.1073/pnas.56.1.72

141. Calandra T, Bernhagen J, Mitchell RA, Bucala R. The macrophage is an important and previously unrecognized source of macrophage migration inhibitory factor. J Exp Med (1994) 179(6):1895-902. doi:10.1084/ jem.179.6.1895

142. Bacher M, Metz CN, Calandra T, Mayer K, Chesney J, Lohoff M, et al. An essential regulatory role for macrophage migration inhibitory factor in T-cell activation. Proc Natl Acad Sci U S A (1996) 93(15):7849-54. doi:10.1073/ pnas.93.15.7849

143. Nishihira J, Koyama Y, Mizue Y. Identification of macrophage migration inhibitory factor (MIF) in human vascular endothelial cells and its induction by lipopolysaccharide. Cytokine (1998) 10(3):199-205. doi:10.1006/ cyto.1997.0276

144. Wymann D, Bluggel M, Kalbacher H, Blesken T, Akdis CA, Meyer HE, et al. Human B cells secrete migration inhibition factor (MIF) and present a naturally processed MIF peptide on HLA-DRB $1^{*} 0405$ by a FXXL motif. Immunology (1999) 96(1):1-9. doi:10.1046/j.1365-2567.1999.00652.x

145. Chen L, Yang G, Zhang X, Wu J, Gu Q, Wei M, et al. Induction of MIF expression by oxidized LDL via activation of NF-kappaB in vascular smooth muscle cells. Atherosclerosis (2009) 207(2):428-33. doi:10.1016/j. atherosclerosis.2009.05.021

146. Simons D, Grieb G, Hristov M, Pallua N, Weber C, Bernhagen J, et al. Hypoxia-induced endothelial secretion of macrophage migration inhibitory factor and role in endothelial progenitor cell recruitment. J Cell Mol Med (2011) 15(3):668-78. doi:10.1111/j.1582-4934.2010.01041.x

147. Calandra T, Bernhagen J, Metz CN, Spiegel LA, Bacher M, Donnelly T, et al. MIF as a glucocorticoid-induced modulator of cytokine production. Nature (1995) 377(6544):68-71. doi:10.1038/377068a0

148. LeechM,MetzC,HallP,HutchinsonP,GianisK,SmithM,etal.Macrophagemigration inhibitory factor in rheumatoid arthritis: evidence of proinflammatory functionand regulationbyglucocorticoids. ArthritisRheum (1999) 42(8):16018. doi:10.1002/1529-0131(199908)42:8<1601::AID-ANR6>3.0.CO;2-B

149. Calandra T, Echtenacher B, Roy DL, Pugin J, Metz CN, Hultner L, et al. Protection from septic shock by neutralization of macrophage migration inhibitory factor. Nat Med (2000) 6(2):164-70. doi:10.1038/72262

150. Mawhinney L, Armstrong ME, O’Reilly C, Bucala R, Leng L, Fingerle-Rowson G, et al. Macrophage migration inhibitory factor (MIF) enzymatic activity and lung cancer. Mol Med (2014) 20:729-35. doi:10.2119/molmed.2014.00136

151. Leng L, Metz CN, Fang Y, Xu J, Donnelly S, Baugh J, et al. MIF signal transduction initiated by binding to CD74. J Exp Med (2003) 197(11):1467-76. doi:10.1084/jem.20030286

152. Borghese F, Clanchy FI. CD74: an emerging opportunity as a therapeutic target in cancer and autoimmune disease. Expert Opin Ther Targets (2011) 15(3):237-51. doi:10.1517/14728222.2011.550879

153. Shi X, Leng L, Wang T, Wang W, Du X, Li J, et al. CD44 is the signaling component of the macrophage migration inhibitory factor-CD74 receptor complex. Immunity (2006) 25(4):595-606. doi:10.1016/j.immuni.2006.08.020

154. Bernhagen J, Krohn R, Lue H, Gregory JL, Zernecke A, Koenen RR, et al. MIF is a noncognate ligand of CXC chemokine receptors in inflammatory and atherogenic cell recruitment. Nat Med (2007) 13(5):587-96. doi:10.1038/ nm1567

155. Schwartz V, Lue H, Kraemer S, Korbiel J, Krohn R, Ohl K, et al. A functional heteromeric MIF receptor formed by CD74 and CXCR4. FEBS Lett (2009) 583(17):2749-57. doi:10.1016/j.febslet.2009.07.058

156. Lue H, Kapurniotu A, Fingerle-Rowson G, Roger T, Leng L, Thiele M, et al. Rapid and transient activation of the ERK MAPK signalling pathway by macrophage migration inhibitory factor (MIF) and dependence on JAB1/ CSN5 and Src kinase activity. Cell Signal (2006) 18(5):688-703. doi:10.1016/j. cellsig.2005.06.013

157. Sun J, Hartvigsen K, Chou MY, Zhang Y, Sukhova GK, Zhang J, et al. Deficiency of antigen-presenting cell invariant chain reduces atherosclerosis in mice. Circulation (2010) 122(8):808-20. doi:10.1161/ CIRCULATIONAHA.109.891887

158. Chatterjee M, Borst O, Walker B, Fotinos A, Vogel S, Seizer P, et al. Macrophage migration inhibitory factor limits activation-induced apoptosis of platelets via CXCR7-dependent Akt signaling. Circ Res (2014) 115(11):939-49. doi:10.1161/CIRCRESAHA.115.305171

159. Lin SG, Yu XY, Chen YX, Huang XR, Metz C, Bucala R, et al. De novo expression of macrophage migration inhibitory factor in atherogenesis in rabbits. Circ Res (2000) 87(12):1202-8. doi:10.1161/01.RES.87.12.1202

160. Burger-Kentischer A, GobelH, Kleemann R,Zernecke A, Bucala R, Leng L, etal. Reduction of the aortic inflammatory response in spontaneous atherosclerosis by blockade of macrophage migration inhibitory factor (MIF). Atherosclerosis (2006) 184(1):28-38. doi:10.1016/j.atherosclerosis.2005.03.028

161. Schober A, Bernhagen J, Thiele M, Zeiffer U, Knarren S, Roller M, et al. Stabilization of atherosclerotic plaques by blockade of macrophage migration inhibitory factor after vascular injury in apolipoprotein E-deficient mice. Circulation (2004) 109(3):380-5. doi:10.1161/01.CIR.0000109201.72441.09

162. Cheng Q, McKeown SJ, Santos L, Santiago FS, Khachigian LM, Morand EF, et al. Macrophage migration inhibitory factor increases leukocyte-endothelial interactions in human endothelial cells via promotion of expression of adhesion molecules. J Immunol (2010) 185(2):1238-47. doi:10.4049/jimmunol.0904104

163. Pan JH, Sukhova GK, Yang JT, Wang B, Xie T, Fu H, et al. Macrophage migration inhibitory factor deficiency impairs atherosclerosis in low-density lipoprotein receptor-deficient mice. Circulation (2004) 109(25):3149-53. doi:10.1161/01.CIR.0000134704.84454.D2

164. Wirtz TH, Tillmann S, Strussmann T, Kraemer S, Heemskerk JW, Grottke O, et al. Platelet-derived MIF: a novel platelet chemokine with distinct recruitment properties. Atherosclerosis (2015) 239(1):1-10. doi:10.1016/j. atherosclerosis.2014.12.039

165. Boisvert WA, Santiago R, Curtiss LK, Terkeltaub RA. A leukocyte homologue of the IL-8 receptor CXCR-2 mediates the accumulation of macrophages in atherosclerotic lesions of LDL receptor-deficient mice. J Clin Invest (1998) 101(2):353-63. doi:10.1172/JCI1195

166. Boisvert WA, Rose DM, Johnson KA, Fuentes ME, Lira SA, Curtiss LK, et al. Up-regulated expression of the CXCR2 ligand KC/GRO-alpha in atherosclerotic lesions plays a central role in macrophage accumulation and lesion progression. Am J Pathol (2006) 168(4):1385-95. doi:10.2353/ajpath.2006.040748

167. Chen Z, Sakuma M, Zago AC, Zhang X, Shi C, Leng L, et al. Evidence for a role of macrophage migration inhibitory factor in vascular disease. Arterioscler Thromb Vasc Biol (2004) 24(4):709-14. doi:10.1161/01.ATV.0000119356.35748.9e

168. Noels H, Bernhagen J, Weber C. Macrophage migration inhibitory factor: a noncanonical chemokine important in atherosclerosis. Trends Cardiovasc Med (2009) 19(3):76-86. doi:10.1016/j.tcm.2009.05.002

169. White DA, Su Y, Kanellakis P, Kiriazis H, Morand EF, Bucala R, et al. Differential roles of cardiac and leukocyte derived macrophage migration inhibitory factor in inflammatory responses and cardiac remodelling post myocardial infarction. J Mol Cell Cardiol (2014) 69:32-42. doi:10.1016/j. yjmcc.2014.01.015

170. Liehn EA, Kanzler I, Konschalla S, Kroh A, Simsekyilmaz S, Sönmez TT, et al. Compartmentalized protective and detrimental effects of endogenous macrophage migration-inhibitory factor mediated by CXCR2 in a mouse model of myocardial ischemia/reperfusion. Arterioscler Thromb Vasc Biol (2013) 33(9):2180-6. doi:10.1161/ATVBAHA.113.301633

Conflict of Interest Statement: The authors declare that the research was conducted in the absence of any commercial or financial relationships that could be construed as a potential conflict of interest.

Copyright $\odot 2015$ van der Vorst, Döring and Weber. This is an open-access article distributed under the terms of the Creative Commons Attribution License (CC BY). The use, distribution or reproduction in other forums is permitted, provided the original author(s) or licensor are credited and that the original publication in this journal is cited, in accordance with accepted academic practice. No use, distribution or reproduction is permitted which does not comply with these terms. 